\title{
KAJIAN PEMANFAATAN TUMBUHAN OBAT OLEH MASYARAKAT DESA LABIAN IRA'ANG KECAMATAN BATANG LUPAR KABUPATEN KAPUAS HULU
}

\author{
(The Study of Medicinal Plants by the Villagers of Labin Ira'ang Batang Lupar District of \\ Kapuas Upstream District)
}

\author{
Ignasius Tuah, M. Dirhamsyah, Gusti Eva Tavita \\ Fakultas Kehutanan Universitas Tanjungpura Jl. Daya Nasional, Pontianak 78124 \\ E-mail: ingnasiustuah@yahoo.co.id
}

\begin{abstract}
Medicinal plants are all types of plants that produce one or more active components that are used for health care and treatment or all parts of plants that are known or believed to have medicinal properties (Allo 2010). The purpose of this study was to determine the types of medicinal plants used by the community, to find out how to mix types of medicinal plants by the people of Labian Ira'ang Village, Batang Lupar Hulu District. This study used the Snowball Sampling technique or carried out in a chain manner by asking for information on the person who had been interviewed or contacted before and so on. Based on the results of research in the field, the people of Labian Ira'ang Village obtained 34 types of medicinal plants which were used for traditional medicine ingredients. The types of medicinal plants used are included in 24 families. The plant parts used by the people of Labian Ira'ang Village as medicine are roots, stems, fruit and leaves, flowers, sap, fruit, skin, rhizomes, tubers, young shoots and shoots. The most widely used part is the leaves of 16 types and the least used Are the seeds, sap, and flower Sofe ach type.
\end{abstract}

Keywords: Labian Ira'ang Village, Plant Type, Utilization.

\section{PENDAHULUAN}

Tumbuhan

merupakan

keanekaragaman hayati yang selalu ada di sekitar kita, baik yang tumbuh liar maupun yang sudah dibudidayakan. Sejak jaman dahulu tumbuhan sudah digunakan sebagai obat tradisional yang penggunaannya diwariskan secara turun temurun. Tujuan penelitian ini adalah Untuk mengetahui jenis-jenis tumbuhan, bagian tumbuhan yang dimanfaatkan masyarakat serta cara meramu tanaman obat di Desa Labian Ira'ang Kecamatan Batang Lupar Kabupaten Kapuas Hulu.

Keuntungan obat tradisional yang dirasakan langsung oleh masyarakat adalah kemudahan untuk memperolehnya dan bahan bakunya dapat di tanam di pekarangan sendiri, murah dan dapat diramu sendiri di rumah. maka pemanfaatan tumbuhan sebagai obat untuk kepentingan kesehariaannya bukanlah merupakan hal yang baru tetapi sudah berlangsung cukup lama. Menurut kutipan dari Jaini (1993) tumbuhan obat adalah tumbuhan yang bagian tubuhnya (akar, batang, kulit, daun, umbi, buah, biji dan getah) mempunyai khasiat obat dan digunakan sebagai bahan mentah dalam pembuatan obat moderen dan tradisiional.

Masyarakat Desa Labian Ira'ang Kecamatan Batang Lupar Kabupaten 
Kapuas Hulu merupakan masyarakat yang hidup berdampingan dengan hutan dan bahkan ketergantungan hidupnya dengan lingkungan hutan, untuk mempertahan kehidupannya sehari-hari masyarakat Dusun Bakul dapat mengambil tumbuhan tanaman jenis obat-obatan yang mereka anggap sebagai obat yang dapat menyembuhkan jenis penyakit yang ada.

Tujuan dari penelitian di Desa Labian Ira'ang Kecamatan Batang Lupar Kabupaten Kapuas Hulu adalah Untuk mengetahui jenis-jenis tanaman obat apa saja yang di manfaatkan masyarakat Desa Labian Ira'ang Kecamatan Batang Lupar, Untuk mengetahui bagian tumbuhan obat yang dimanfaatkan sebagai obat untuk menyembuhkan suatu penyakit, Untuk mengetahui cara meramu jenis tanaman obat yang dilakukan oleh masyarakat Desa Labian Ira'ang Kecamatan Batang Lupar Hulu. dan manfaat penelitian tumbuhan yaitu diharapkan dapat menyediakan informasi berupa dokumen tertulis tentang khasiat dan jenis tumbuhan yang dimanfaatkan oleh masyarakat serta dokumentasi mengenai pemanfaatan tumbuhan obat yang ada di sekitarn Desa Labian Ira'ang Kecamatan Batang Lupar Kabupaten Kapuas Hulu.

Keuntungan obat tradisional yang dirasakan langsung oleh masyarakat adalah kemudahan untuk memperolehnya dan bahan bakunya dapat di tanam di pekarangan sendiri, murah dan dapat diramu sendiri di rumah. maka pemanfaatan tumbuhan sebagai obat untuk kepentingan kesehariaannya bukanlah merupakan hal yang baru tetapi sudah berlangsung cukup lama. Data tentang pemanfaatan obat oleh masyarakat Desa Labian belum diketahui sepenuhnya hanya dari pengalan saja.

\section{METODE PENELITIAN}

Penelitian ini dilakukan di Desa Labian Ira'ang Kecamatan Batang Lupar Kabupaten Kapuas Hulu, Selama 4 minggu efektif di lapangan. Metode yang digunakan dalam penelitian ini adalah metode Snowball Sampling atau dilakukan secara berantai dengan meminta informasi pada orang yang telah di wawancarai atau dihubungi sebelumnya demikian seterusnya Teknik ini melibatkan informan yang berhubungan dengan penelitian yaitu dengan mewancarai pimpinan masyarakat seperti tokoh masyarakat Kepala Suku, Kepala Desa, Kepala Kampung dan sumber terpercaya lainnya yang mengetahui dan memanfaatan tumbuhan sebagai bahan obat. Seperti tabib atau dukun untuk pengobatan umum, dukun beranak ataupun masyarakat umum. Informasi dari informan yang pertama diharapkan dapat tahu siapa saja di daerah tersebut yang mengetahui dan memanfaatkan tumbuhan obat.

Objek penelitian ini adalah masyarakat Desa Labian Ira'ang dan jenisjenis tumbuhan yang digunakan masyarakat tersebut secara tradisional sebagai obat. Alat yang digunakan adalah kamera untuk dokumentasi. Alat tulis menulis untuk mencatat data yang di peroleh di lapangan, daftar pertanyaan atau kuesioner untuk responden yang dianggap mengerti tentang tanaman obat, GPS (Global Positioning Sistem) untuk menentukan posisi atau titik objek penelitian, Buku daftar tumbuhan obat 
untuk identifkasi jenis tumbuhan obat

Di Kalimantan Barat Jilid 1 dan jilid 2. yaitu Ragam Tumbuhan Berkhasiat Obat
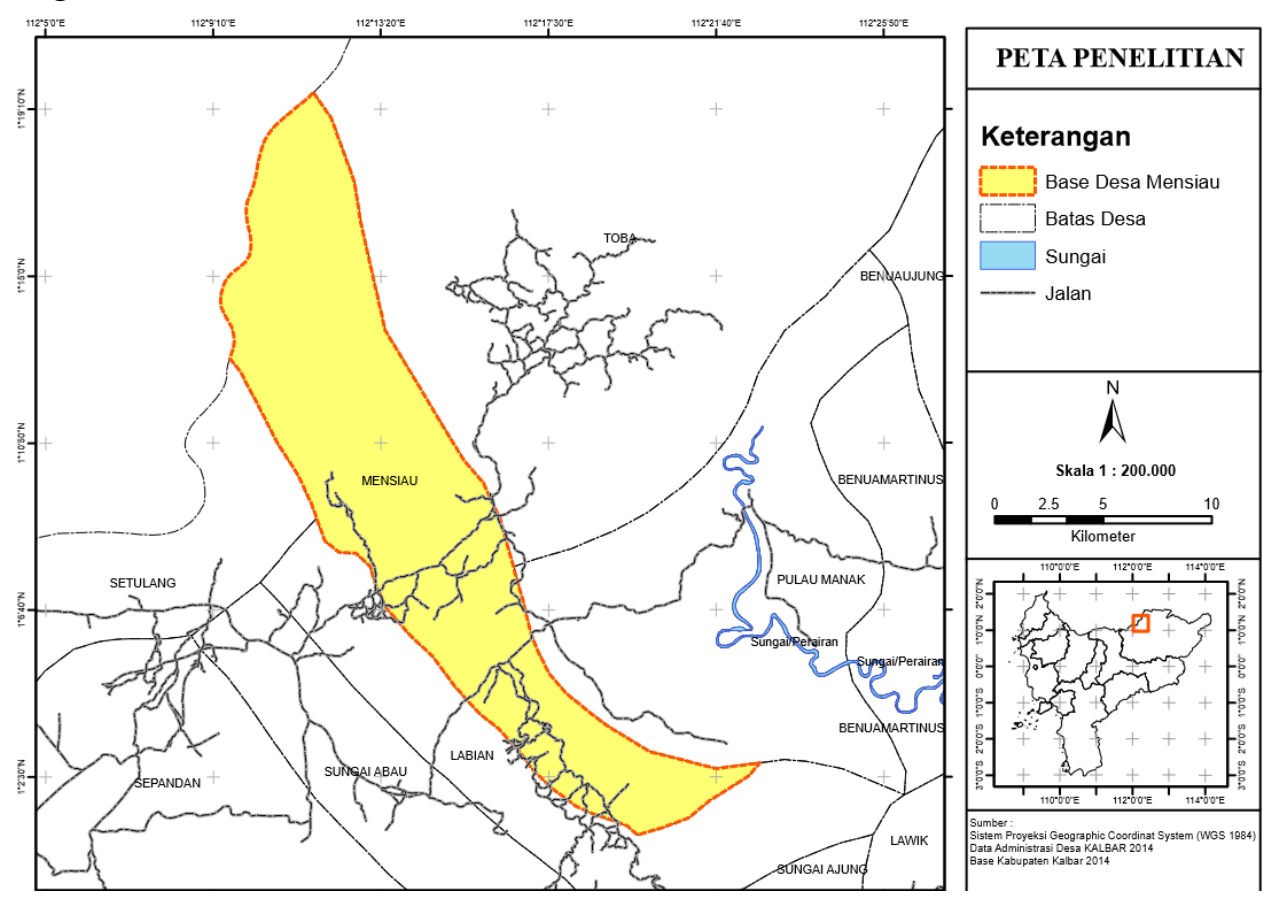

Gambar 1 : Peta Lokasi Penelitian Tanaman Obat di Desa Labian Ira'ang ( Map of Medicinal Plant Research Locations in the Labian Ira'ang Village)

HASIL DAN PEMBAHASAN

Desa Labian Ira'ang merupakan salah satu daerah yang memiliki kearifan lokal dan masyarakatnya masih menggantungkan hidupnya dengan mengelola dan memanfaatkan hasil hutan disekitarnya. Masyarakat sekitar kawasan hutan mempunyai ketergantungan sangat tinggi pada hutan disekitarnya. Bentuk pemanfaatan hutan adalah keanekaragaman tumbuhan yang digunakan baik untuk pangan, bangunan, pengobatan, aneka anyaman, dan kerajinan.

Berdasarkan hasil penelitian dilapangan, masyarakat Desa Labian Ira'ang diperoleh 34 jenis tumbuhan obat yang dimanfaatkan untuk bahan pengobatan tradisional. Jenis tumbuhan obat yang dimanfaatkan termasuk dalam 24 famili.Famili yang banyak digunakan adalah family Zingiberaceae (5 jenis), famili Poaceae dan Lamiaceae ( 3 jenis ), family Arecaceae (2 jenis) dan yang paling sedikit digunakan dari family Selaginellaceae,

Caricaceae, Bromeliaceae, Solanaceae, Apocynaceae, Fabaceae, Euphorbiaceae, Sterculiaceae, Hypoxidaceae, Thymelaeaceae, Rubiaceae, Melastomataceae, Myrtaceae, Pandanaceae, Annonaceae, Piperaceae, Crassulaceae, Asparagales, Malvaceae, Rutaceae yaitu masing-masing satu jenis.

Habitus tumbuhan yang ditemukan terdiri dari tingkat semak, perdu, herba, pohon, dan liana. Berdasarkan tingkatan habitus tumbuhan, bahwa habitus tumbuhan yang banyak digunakan adalah 
dari tingkat herba (14 jenis), dan yang sedikit adalah dari tingkat liana (1 jenis). Berdasarkan tingkatan habitus tumbuhan yang banyak digunakan adalah dari tingkat herba (17 jenis), dan yang sedikit adalah dari tingkat liana (1 jenis).

\section{Bagian Tumbuhan Yang Digunakan}

Bagian tumbuhan yang digunakan masyarakat Desa Labian Ira'ang sebagai obat adalah akar, batang, buah dan daun, bunga, getah, buah, kulit, rimpang, umbi, tunas yang muda, dan pucuk. Bagian yang banyak digunakan adalah daun sebanyak 16 jenis dan yang sedikit digunakan adalah bagian biji, getah, dan bunga masingmasing 1 jenis.

Persentase bagian tumbuhan yang digunakan sebagai obat sebagai berikut:

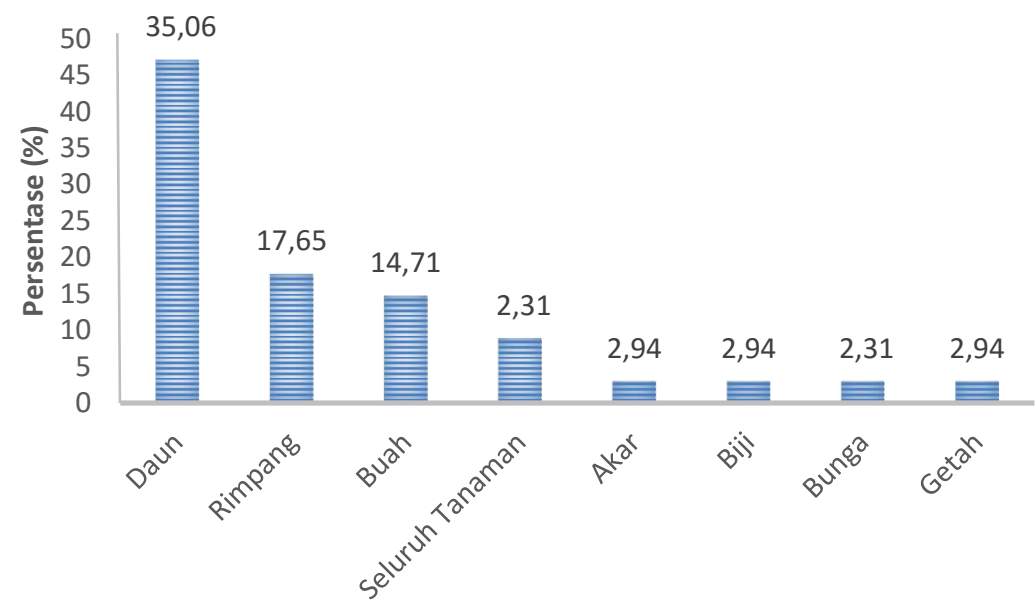

Gambar 2 : Persentase Bagian Tumbuhan yang Digunakan (percentage of Plant Parts Used)

Untuk persentase bagian tumbuhan yang digunakan menunjukan bahwa paling banyak digunakan adalah daun sebanyak $(35,06 \%)$, rimpang $(17,65 \%)$, buah $(14,71 \%)$, seluruh tanaman sebanyak $(2,31 \%)$, dan yang paling sedikit digunakan adalah bagian akar, biji, bunga, getah masing-masing $(2,94 \%)$.

\section{Cara Pengolahan}

Berdasarkan hasil wawancara dengan masyarakat, cara pengolahan tumbuhan obat oleh masyarakat Desa Labian Ira'ang diantaranya yaitu : a). Obat yang dimakan : bahan ditumbuk, dikunyah atau dimakan mentah.

b). Obat yang diminum : bahan direbus, diseduh air panas dan airnya diminum. c). Penggunaan luar : dibakar, ditempel, diremas, dioleskan dan digosok pada bagian yang sakit atau luka. Cara pengolahan tumbuhan obat yang sering dilakukan masyarakat yaitu dengan cara direbus. Persentase cara pengolahan tumbuhan obat disajikan berikut ini : 


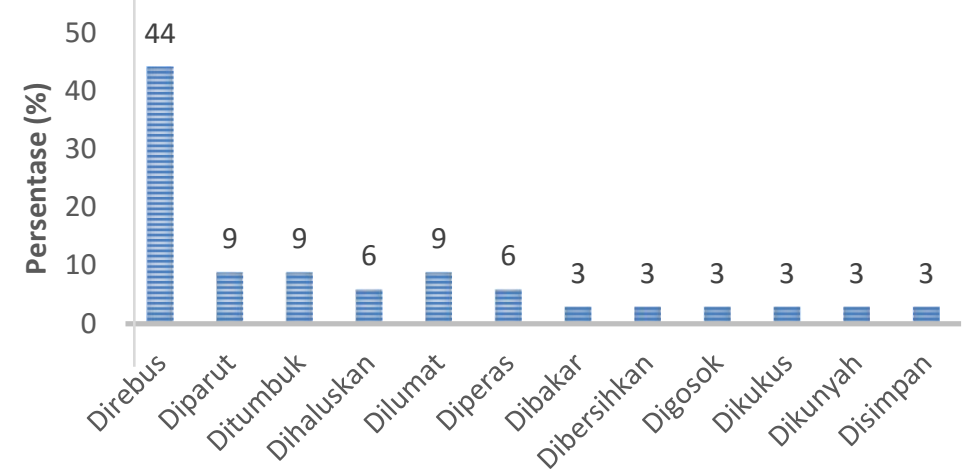

Gambar 3 : Persentase Cara Pengolahan Tumbuhan Obat (Percentage of Ways to Manage Medicinal Plan)

Berdasarkan gambar di atas menunjukan bahwa pengolahan tumbuhan obat yg paling sering dilakukan adalah direbus sebanyak (44\%), sedangkan pengolahan dengan cara diparut, ditumbuk, dilumat, sebanyak (9\%), dan persentase yang jarang digunakan adalah pengolahan dengan cara dibakar, dibersihkan, digosok, dikukus, dikunyah, disimpan sebanyak (3\%).

\section{Cara Penggunaan}

Tumbuhan obat yang digunakan masyarakat Desa Labian Ira'ang dapat berfungsi untuk mengobati berbagai jenis penyakit seperti koreng, diare, diabetes, malaria, sakit perut, luka, panu, hingga tumor. Cara penggunaan obat tersebut antara lain dibalut, digosok, dimakan, dimakan langsung, diminum, dioles, dan ditempel.

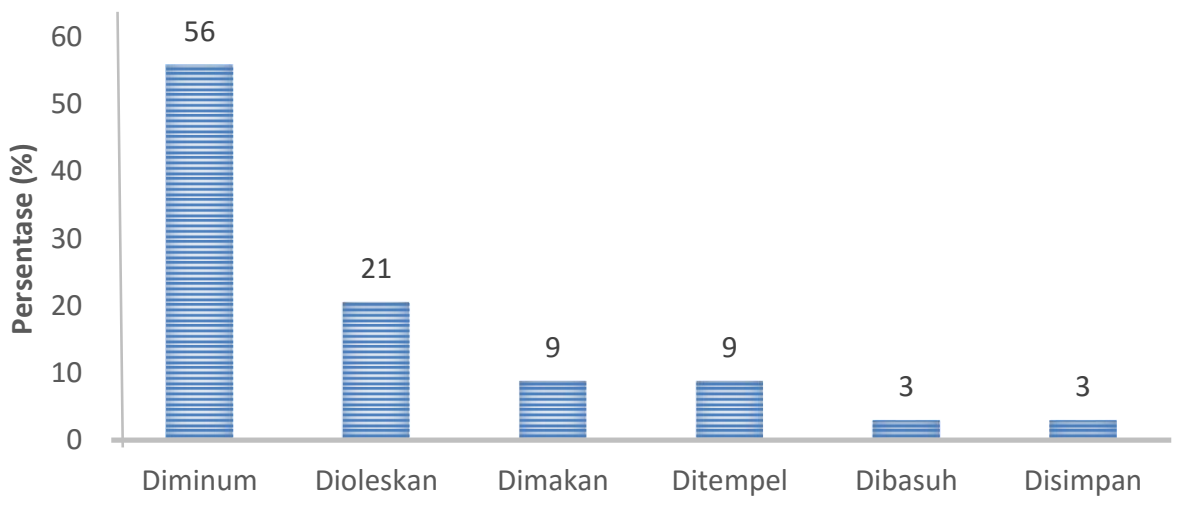

Gambar 4: Persentase Cara Penggunaan Tumbuhan Obat (Percentage of How to Use Medicinal Plants)

Untuk cara penggunaan tumbuhan obat menunjukan bahwa cara yang sering digunakan masyarakat setempat yaitu dengan cara diminum sebanyak (56\%), sedangkan dengan cara di oles sebanyak
(21\%), dimakan, ditempel (9\%), dan yang paling jarang digunakan adalah di basuh dan di simpan sebanyak (3\%).

Berdasarkan hasil penelitian di lapangan diketahui bahwa masyarakat 
setempat yang berada di Desa Labian Ira'ang dengan mewawancarai 10 responden diperoleh 34 jenis tumbuhan termasuk dalam 24 famili yang bermanfaat sebagai tumbuhan obat. Penelitian pemanfaatan tumbuhan obat oleh etnis tertentu pada tempat yang berbeda juga pernah dilakukan oleh Astria (2013) dalam penelitian tentang Kajian Etnobotani Tumbuhan Obat di Dusun Semoncol Kecamatan Balai Kabupaten Sanggau, diperoleh 51 jenis tumbuhan yang dimanfaatkan sebagai obat, berbeda dengan penelituan terdahulu ternyata masing masing daerah ditemukan jenisjenis tanaman obat seperti pada Hutan Adat Bukit Padarang Dusun Marinso Kabupaten Landak dengan suku dayak hanya menggunakan 30 jenis tumbuhan obat habitus yang paling banyak digunakan adalah tingkat pohon (Armiwoltywa, 2011).

Di Desa Sekabuk Kecamatan Sadaniang Kabupaten Pontianak dengan suku dayak menggunakan tumbuhan obat 51 jenis, habitus yg paling banyak ditemukan dan dimanfaatkan adalah tingkat pohon (Leonardo, 2012). Perbedaan kondisi lingkungan pada masing-masing daerah menyebabkan perbedaan untuk jenis-jenis tumbuhan yang tumbuh pada daerah tersebut.

Berdasarkan hasil wawancara dengan responden terpilih yaitu pak Sumbu (54 tahun) sebagai ketua adat Desa Sembawang dan juga yang sudah membudidayakan tumbuhan obat menyatakan bahwa ada 11 jenis tumbuhan obat yang sering digunakan oleh masyarakat Desa Labian Ira'ang yaitu dari famili Zingiberaceae, famili Poaceae dan Lamiacea. Penyakit yang dialami oleh masyarakat setempat dapat disebabkan oleh perubahan lingkungan (cuaca), diabetes, dan disentri. Sakit panas disebabkan oleh perubahan lingkungan (cuaca) seperti hujan dan panas, sakit panas dan batuk oleh masyarakat Desa Labian Ira'ang dapat diobati dengan cara meremas atau menumbuk daun tabu (Sacharum offinarium, Linn) dan diminum air nya.

Penyakit diabetes oleh masyarakat Desa Labian Ira'ang dapat diobati dengan cara meminum air rebusan Tapak Dara (Catharantus roseus). Disentri dapat disebabkan karena tidak menjaga kebersihan lingkungan dan kebiasaan hidup bersih oleh masyarakat Desa Labian Ira'ang dapat diobati dengan cara meminum air rebusan Mahkota Dewa (Phaleria macrocorpa). Tumbuhan obat yang dimanfaatkan oleh masyarakat Desa Labian Ira'ang paling banyak ditemukan di kebun yaitu sebanyak 34 jenis tumbuhan obat karena masyarakat secara sengaja menanam atau membudidayakan tumbuhan obat tersebut.

Tumbuhan obat yang dimanfaatkan oleh masyarakat Desa Labian Ira'ang yang ditemukan di hutan seperti Lambak (Curculigo latifolia), ditemukan di kebun seperti Unti Sangkaling (Carica papaya, Linn), dan ditemukan di pekarangan seperti jambu biji (Psidium guajava). Masyarakat di Desa Labian Ira'ang memanfaatkan tumbuhan obat untuk mengobati berbagai penyakit karena penggunaan tumbuhan obat ini jauh lebih baik dan tidak ada efek sampingnya. 
Tumbuhan obat juga bisa digunakan untuk bahan bumbu dapur seperti kunyit (Curcuma domestica), cekur (Kaempferia galanga), serai (Cymbopogon nardus), kribang (Manihot utilisima), dan papaya (Carica papaya). Ketersediaan tumbuhan obat yang tumbuh dihutan langka dan susah didapatkan, maka dari itu masyarakat Desa Labian Ira'ang sudah membudidayakan tumbuhan obat, mereka sadar jika tidak dibudidayakan maka tumbuhan obat akan habis. Pemanfaatan tumbuhan obat oleh masyarakat setempat, sedikit sekali yang memberikan dampak negatif terhadap kelestarian hutan.

Pengobatan tradisional berkaitan erat dengan pelestarian pemanfaatan sumber daya hayati dalam hal ini adalah tumbuhan obat yang sudah teruji khasiatnya untuk menyembuhkan berbagai penyakit berdasarkan pengalaman masyarakat, sehingga dengan mengetahui manfaat tumbuhan obat tradisional maka langkahlangkah pelestarian dapat dilakukan secara terpadu.

Jenis tumbuhan obat yang sudah dibudidayakan ada 27 jenis tumbuhan obat yaitu Temulawak, Kunyit, Lengkuas, Sirih, Kemuning, Pepaya, Singkara, Cocor bebek, Kaliansang, Mengkudu, Kumis kucing, Babari, Lidah mertua, Jambu biji, Jahe, Cacar danum, Kencur, Cocor bebek, Akar kuning, Sirsak, Kalamunting, Kemangi, Mahkota dewa, Cabai merah, Serai wangi, dan Nampu, dari 27 jenis tumbuhan obat tersebut semuanya mudah dibudidayakan. tumbuhan yang mudah didapat dan tidak perlu ditanam khusus yaitu Langsat, Bulu Baba, Kemuning, Bambu kuning, Belimbing, Bunga Jabang,
Cangkok, Bunga Kapal, Baulu, Kaliansang, Durian Balanda, Cacar Danum, Kalamunting, Ilung, Kemunting, Daun singkong, Jambu Kayu, Pakuk karu, Pasak bumi, Mahkota Dewa, Singkara, Cocorbebek, Unti Babari, dan Tapak dara karena mudah tumbuh di sekitar rumah atau kebun.

Kelompok famili yang ditemukan di Desa Labian Ira'ang adalah famili Zingiberaceae (5 jenis), famili Poaceae dan Lamiaceae (3 jenis ), family Arecaceae (2 jenis) dan yang paling sedikit digunakan dari family Selaginellaceae, Caricaceae, Bromeliaceae, Solanaceae, Apocynaceae, Fabaceae, Euphorbiaceae, Sterculiaceae, Hypoxidaceae, Thymelaeaceae Rubiaceae, Melastomataceae, Myrtaceae, Pandanaceae, Annonaceae, Piperaceae, Crassulaceae, Asparagales, Malvaceae, dan Rutaceae. Habitus tumbuhan yang ditemukan terdiri dari tingkat perdu, herba, pohon, dan liana. Berdasarkan tingkatan habitus tumbuhan yang banyak digunakan adalah dari tingkat herba (17 jenis), dan yang sedikit adalah dari tingkat liana (1 jenis).

Berdasarkan habitatnya tumbuhan obat yang ditemukan tempat tumbuhnya adalah di tanah kuning, tanah basah, dalam pot, tanah rawa, pegunungan/ tumbuhan alam, pegunungan/ budidaya, dan tempat tumbuh yang paling banyak ditemukan adalah di tanah kuning, sedangkan penyebarannya sendiri ternyata lebih banyak ditemukan di perkarangan rumah dan kebun tanaman obat (Toga) supaya lebih mudah di ambil dan digunakan. 
Bagian tumbuhan yang digunakan masyarakat Desa Labian Ira'ang sebagai obat adalah akar, batang, buah dan daun, bunga, getah, buah, kulit, rimpang, umbi, tunas yang muda, dan pucuk. Bagian yang banyak digunakan adalah daun sebanyak 16 jenis dan yang sedikit digunakan adalah bagian biji, getah, dan bunga masingmasing 1 jenis .

Berdasarkan hasil wawancara dengan masyarakat, cara pengolahan tumbuhan obat oleh masyarakat Desa Labian Ira'ang diantaranya yaitu :

1) Obat yang dimakan : bahan ditumbuk, dikunyah atau dimakan mentah.

2) Obat yang diminum : bahan direbus, diseduh air panas dan airnya diminum.

3) Penggunaan luar : dibakar, ditempel, diremas, dioleskan dan digosok pada bagian yang sakit atau luka. Cara pengolahan tumbuhan obat yang sering dilakukan masyarakat yaitu dengan cara direbus.

Cara penggunaan tumbuhan obat yang sering digunakan masyarakat setempat yaitu dengan cara diminum, dioles, dimakan, ditempel, dan yang paling jarang digunakan adalah di basuh dan di simpan misalnya keputihan dan penetralisir gas beracun dikarenakan masyarakat setempat menggunakan resep dari dokter atau bidan.

Tumbuhan obat diolah dengan dua cara berdasarkan banyaknya jenis tanaman yang digunakan yaitu:

a. Diolah secara tunggal, artinya hanya menggunakan satu jenis tanaman, dan mengolahnya dengan cara tidak mencampur tumbuhan tersebut dengan bahan atau tumbuhan lain. b. Diolah secara campuran, artinya menggunakan beberapa jenis tanaman dan mengolahnya dengan mencampur beberapa jenis tumbuhan tersebut dengan bahan atau tumbuhan lain.

Dari hasil penelitian ditemukan bahwa masyarakat di Desa Labian Ira'ang mengolah tumbuhan obat secara tunggal hanya menggunakan satu jenis tanaman, dan mengolahnya dengan cara tidak mencampur tumbuhan tersebut dengan bahan atau tumbuhan lain.

\section{KESIMPULAN}

Berdasarkan hasil penelitian dilapangan tumbuhan obat yang paling banyak ditemukan yaitu sebanyak 34 jenis tumbuhan obat yang tergolong dalam 24 famili yang sering dimanfaatkan oleh masyarakat sebagai obat, dimana pengolahannya masih secara tradisional yaitu hanya berdasarkan kebiasaan dan pengalaman saja, jenis tanaman obat yang paling banyak dimanfaatkan oleh masyarakat setempatyaitu tingkat herba, dan bagian daun yang lebih banyak dimanfaatkan, dan satu jenis tumbuhan bisa untuk mengobati lebih dari satu jenis penyakit.

\section{SARAN}

Pengetahuan tumbuhan obat perlu di dokumentasikan secara tertulis dan sebaiknya dapat diturunkan kepada generasi yang lebih muda, perlu dilakukan pendekatan kepada masyarakat tentang cara pemanfaatan tumbuhan obat tanpa menyampingkan faktor kelestariannya, terutama cara melakukan budidaya tumbuhan obat serta Perlu dilakukan penelitian lanjutan mengenai cara 
perbanyakan jenis atau regenerasi tumbuhan obat tradisional yang ada sehingga keberadaannya khususnya didaerah tersebut dapat dipertahankan.

\section{DAFTAR PUSTAKA}

Dalimartha, S. 1999. Atlas Tumbuhan Obat Indonesia. Buku Jilid 1. Trubus Agriwidya, Jakarta.

Dalimartha, S. 2003. Atlas Tumbuhan Obat Indonesia. Buku Jilid 3. Trubus Agriwidya, Jakarta.

Hidayat, D, Hardiansyah, G. 2012. Studi Keanekaragaman Jenis Tumbuhan Obat di Kawasan Kabupaten Sintang.

Isnandar, H. 2008. 1001 Kumpulan Ramuan Obat Tradisional Indonesia. Jawa Timur.

Leonardo, 2013. Kajian Etnobotani Tumbuhan Obat Di Desa Sekabuk Kecamatan Sadaniang Kabupaten Pontianak. Jurnal Hutan Lestari

Waluyo, E.B. 1995. Pengetahuan Masyarakat Tradisional Dalam Biologi Modern. Lokakarya Biologi - Biovillage

Wijayakusuma, H. M. 2008. Ramuan Lengkap Herbal Sembuhkan Penyakit. PustakaBunda.

Zuhud, E. A. M. Hidayat. 2009. Potensi Hutan Tropika Indonesia sebagai penyanggabahan obat alam untuk kesehatan bangsa. Jakarta. 